\title{
Effect of Integrated Nutrient Management on Nutrient Content, Uptake and Yield of Rice Crop in Inceptisol
}

\author{
Yugal Kishor Sahu* and A. K. Chaubey \\ Department of Soil Science and Agricultural Chemistry, Indira Gandhi Krishi \\ Vishwavidyalaya, Raipur-492012, India \\ *Corresponding author
}

A B S T R A C T

\begin{tabular}{l} 
K e y w o r d s \\
INM, Rice, \\
Yield, Content, \\
Uptake, Inceptisol \\
Article Info \\
$\begin{array}{l}\text { Accepted: } \\
\text { 20 February } 2020 \\
\text { Available Online: } \\
\text { 10 March } 2020\end{array}$ \\
\hline
\end{tabular}

A study was conducted to find out the effect of integrated nutrient management on nutrient content, uptake and yield of rice crop in Inceptisol at College of Agriculture and Research Station, Janjgir-Champa, IGKV, Raipur during kharif season of 2014.The application of soil test crop response (STCR) dose (125:50:46) with $5 \mathrm{t}$ FYM for YT $50 \mathrm{q} \mathrm{ha}^{-1}$ recorded significantly higher uptake of N, P and K in rice followed by $100 \%$ GRD+5 t FYM ha ${ }^{-1}$ over controlat30,60 DAT and harvesting stage of rice. Where as the $\mathrm{N}, \mathrm{P}$ and $\mathrm{K}$ content at different stages of rice was found non-significant. The yield of rice was significantly higher in treatment STCR (125:50:46) with $5 \mathrm{t}$ FYM for YT $50 \mathrm{q} \mathrm{ha}^{-1}$ as compare to rest of the treatments, however it was statistically similar to $100 \%$ GRD+ 5 t FYM ha ${ }^{-1}, 100 \%$ GRD+10 kg BGA ha-1 and 100\% GRD (100:60:40).

\section{Introduction}

Rice is intimately involved in the culture as well as the food ways and economy of many societies. It is considered as the gift of god, and it is treated with reverence. Tradition holds that "the precious things are not pearls and jade but the five grains", of which rice is the first. Among the major cereals, though sufficient food is produced on global basis to feed everyone, the pains of hunger continue to be a common experience of many people in the world today, especially in the developing countries and under developed countries because of the rapid population growth.

Rice plant needs a sufficient supply of nutrients from several sources for optimal growth. These nutrients are supplied by indigenous sources such as soil minerals, soil organic matter, rice straw, manure, and water (rain, irrigation), but the amount supplied is usually insufficient to achieve high and sustainable yields. However, the use of organic manures alone might not meet the plant requirement due to presence of 
relatively low levels of nutrients. Therefore, in order to make the soil well supplied with all the plant nutrients in the readily available form and to maintain good soil health, it is necessary to use organic manures in conjunction with inorganic fertilizers to obtain optimum yields (Rama Lakshmi et al., 2012).

Soil fertility deterioration is a major constraint for higher crop production. The increasing land use intensity without adequate and balanced use of chemical fertilizers with little or no use of organic manure have caused severe fertility deterioration of our soils resulting in stagnating or even declining of crop productivity. Integration of chemical and organic sources like manures, biofertilizers etc. and their efficient management does not only help in sustaining the productivity and physical and biological health of soil but also meets a part of the chemical fertilizer requirement of crops (Babu et al. 2007).

Verma et al., 2005 was also revealed that the integration of inorganic fertilizers with organic manures will not only sustain the crop production but also will be effective in improving soil health and enhancing the nutrient use efficiency. Thus, it is necessary to apply nutrients from organic sources in order to obtain sustainable crop yield without affecting soil fertility. Keeping these points in view, the present investigation was undertaken to study the Effect of Integrated Nutrient Management on Nutrient Content, Uptake and Yield of Rice crop in Inceptisol.

\section{Materials and Methods}

A field experiment was conducted during kharif season of 2014 to study the effect of integrated nutrient management on nutrient content, uptake and yield of rice in Inceptisol at the Research Farm, College of Agriculture and Research Station, Janjgir-Champa, IGKV,
Raipur located at north Mahanadi and the centre of Chhattisgarh and lies between $21^{\circ} 06^{\prime}$ to $22^{\circ} 04^{\prime}$ North latitude and $82^{\circ} 03^{\prime}$ to $83^{\circ} 02^{\prime}$ East longitude with an altitude of 294.4 meters above the mean sea level.

The unit plot size was $8 \times 3.4 \mathrm{~m}$. and spaces between plot to plot and replication to replication were 0.6 and $1 \mathrm{~m}$, respectively. The 21 days old seedlings of MTU - 1010 were planted at a spacing of $20 \times 10 \mathrm{~cm}$. The crop matured in about 115-125 days. Nutrients (Chemical fertilizers and Organic manures) were applied as per the treatments. Recommended doses of $\mathrm{P}$ and $\mathrm{K}$ were applied in the form of single superphosphate (SSP) and muriate of potash (MOP) as basal. Urea was applied in 3 equal splits i.e. $1 / 3^{\text {rd }}$ basal, $1 / 3^{\text {rd }}$ at tillering and $1 / 3^{\text {rd }}$ at panicle initiation stages of the rice crop.

The required quantity of basal doses of FYM was applied one month in advance of transplanting. Blue green algae dry flakes were applied after seven days of transplanting in standing water@10 $\mathrm{kg} \mathrm{ha}^{-1}$ as per the treatments. There were 10 treatments of nutrient with three replications in a randomized block design. Initial soil samples were collected and analyzed for nutrient status by adopting standard procedures. The data on initial soil analysis revealed that the soil was sandy loam (Sand: $52 \%$, Silt: $29.2 \%$, Clay: $18.9 \%$ ) in texture, neutral in soil reaction $(\mathrm{pH}$ 6.96) with non-saline conductivity $\left(0.26 \mathrm{dS} \mathrm{m}^{-1}\right)$.

The organic carbon content was $0.27 \%$, and the available $\mathrm{N}$ content was low $\left(202 \mathrm{~kg} \mathrm{ha}^{-1}\right)$, available $\mathrm{P}$ was very low in status $\left(5.3 \mathrm{~kg} \mathrm{ha}^{-}\right.$ ${ }^{1}$ ) and $\mathrm{K}$ content was medium (267 $\left.\mathrm{kg} \mathrm{ha}^{-1}\right)$. Plant samples (straw and grain) were collected at 30, 60 DAT and at harvesting stage and they were dried in oven at $45^{\circ} \mathrm{C}$ until constant dry weight obtained. The plant samples were grinded and used for 
determined NPK content and their uptake by rice crop. The $\mathrm{N}$ content was determined by Microkjeldahl methods as described by Chapman and Pratt, (1961). P content in plant was determined by vanadomolybdate acid yellow color method, using blue filter as described by Jackson (1967).K content plant was determined by flame-photometric method, using diacid digestion system respectively by Jackson (1967). The NPK uptake $\left(\mathrm{kg} \mathrm{ha}^{-1}\right)$ in each treatment was calculated by multiplying NPK content (\%) with dry matter $\left(\mathrm{q} \mathrm{ha}^{-1}\right)$. However, at harvest, the NPK uptake in grain and straw was calculated by multiplying the NPK content (\%) with the yields of grain and straw. The grain and straw yields of rice were recorded at the time of harvest.

\section{Results and Discussion}

\section{Nitrogen content $(\%)$ and uptake $\left(\mathrm{kg} \mathrm{ha}^{-1}\right)$}

The $\mathrm{N}$ contents in plants at 30 and 60 DAT ranged from 2.26 to $2.32 \%$ and 1.58 to 1.63 $\%$ and in grain and straw at harvest ranged from 1.01 to $1.13 \%$ and 0.31 to $0.35 \%$, respectively (Table 1). Use of integrated nutrient management failed to show significant influence on nitrogen contents at any stage of observation.

Nitrogen uptake by shoot at 30 DAT \& 60 DAT varied from 6.32 to 25.82 and 8.03 to $59.25 \mathrm{~kg} \mathrm{ha}^{-1}$ (Table 2). At both the stages treatment STCR dose with $5 \mathrm{t}$ FYM for YT 50 $\mathrm{q}$ ha $^{-1}\left(\mathrm{~T}_{10}\right)$ recorded maximum Nitrogen uptake. At 30 DAT, STCR dose with 5 t FYM for YT $50 \mathrm{q} \mathrm{ha}^{-1}\left(\mathrm{~T}_{10}\right)$ was found statistically superior not over control but also over other treatments except $100 \%$ GRD + $5 \mathrm{t} \mathrm{FYM} \mathrm{ha}^{-1}$ $\left(\mathrm{T}_{5}\right)$. At 60 DAT, STCR dose with 5 t FYM for YT $50 \mathrm{q} \mathrm{ha}^{-1}\left(\mathrm{~T}_{10}\right)$ was found statistically superior not over control but also over other treatments however, $\mathrm{t}$ was found statistically similar with $100 \%$ GRD + 5 t FYM ha $^{-1}\left(\mathrm{~T}_{5}\right)$,
100\% GRD (100:60:40) $\left(\mathrm{T}_{4}\right)$ and 100\% GRD $+10 \mathrm{~kg} \mathrm{BGA} \mathrm{ha}{ }^{-1}\left(\mathrm{~T}_{7}\right)$.

The uptake of $\mathrm{N}$, as influenced by different treatments, by grain, straw and total biomass ranged from 7.71 to $51.70,3.06$ to 18.37 and 10.77 to $69.86 \mathrm{~kg} \mathrm{ha}^{-1}$, respectively and the data are presented in Table 2. There was significant increase in $\mathrm{N}$ uptake by grain, straw and total biomass over control $\left(\mathrm{T}_{1}\right)$ by all treatments except treatment BGA $10 \mathrm{~kg} \mathrm{ha}^{-}$ ${ }^{1}\left(\mathrm{~T}_{3}\right)$.Application of BGA @ $10 \mathrm{~kg} \mathrm{ha}^{-1}\left(\mathrm{~T}_{3}\right)$ could not cause significant increase over control in uptake of $\mathrm{N}$ by grain, straw and total biomass, while application of FYM $5 \mathrm{t}$ $\mathrm{ha}^{-1}\left(\mathrm{~T}_{2}\right)$ and FYM $5 \mathrm{t} \mathrm{ha}^{-1}+$ BGA $10 \mathrm{~kg} \mathrm{ha}^{-1}$ $\left(\mathrm{T}_{9}\right)$ significantly increased uptake of $\mathrm{N}$ over control $\left(\mathrm{T}_{1}\right)$ by grain, straw and total biomass.

The uptake of $\mathrm{N}$ by grain and total biomass was found to be maximum due to STCR dose with $5 \mathrm{t}$ FYM for YT $50 \mathrm{q} \mathrm{ha}^{-1}\left(\mathrm{~T}_{10}\right)$ which was statistically at par with $100 \%$ GRD $+5 \mathrm{t}$ FYM ha ${ }^{-1}\left(\mathrm{~T}_{5}\right)$ and $100 \%$ GRD + $10 \mathrm{~kg}$ BGA $\mathrm{ha}^{-1}\left(\mathrm{~T}_{7}\right)$. The uptake of $\mathrm{N}$ by straw was found maximum $\left(18.37 \mathrm{~kg} \mathrm{ha}^{-1}\right)$ due to treatment $100 \%$ GRD + 5 t FYM ha ${ }^{-1}\left(\mathrm{~T}_{5}\right)$ which was statistically at par with treatments STCR dose with $5 \mathrm{t}$ FYM for YT $50 \mathrm{q} \mathrm{ha}^{-1}\left(\mathrm{~T}_{10}\right), 100 \%$ GRD + 10 kg BGA ha ${ }^{-1}\left(\mathrm{~T}_{7}\right), 100 \%$ GRD(100:60:40) ( $\left.\mathrm{T}_{4}\right)$ and 75\% GRD $+5 \mathrm{t}$ FYM ha ${ }^{-1}\left(\mathrm{~T}_{6}\right)$ in decreasing order.

A critical observation of the data reveals that the performance of treatment STCR dose with $5 \mathrm{t} \mathrm{FYM} \mathrm{for} \mathrm{YT} 50 \mathrm{q} \mathrm{ha}^{-1}\left(\mathrm{~T}_{10}\right)$ and $100 \%$ GRD + 5 t FYM ha $^{-1}\left(\mathrm{~T}_{5}\right)$, in general, was better over other interactions in increasing the uptake of $\mathrm{N}$ in rice. The highest $\mathrm{N}, \mathrm{P}$ and $\mathrm{K}$ uptake was associated with treatment of soil test based N, P and K application, FYM and green manuring. This might be due to added fertilizers, FYM and green manure, as a result better availability of $\mathrm{N}, \mathrm{P}$, and $\mathrm{K}$ in soil to the rice crop (Singh et al., 2006). The lowest $\mathrm{N}$ uptake in control plot by the crops is due to 
the lower yield obtained in these plots. The application of organics and chemical fertilizers increased crop yields that resulted in increased uptake. The increase in nutrient uptake was directly related to the crop yields.

It can be explained on the basis that application of fertilizers along with manures improved initial process of plant growth such as cell division, number of root hairs etc. Enabling the plant to have healthy root system that helped in better absorption of nutrients and moisture from soil (Subehia and Sepehya, 2012). Similar positive influence of nutrients on crop yields and uptake has also been reported by Gupta et al., (2006) and Prasad et al., (2010).

Phosphorus content (\%) and uptake (kg $\mathrm{ha}^{-1}$ )

Data recorded on $\mathrm{P}$ contents in plants at 30 and 60 DAT ranged from 0.55 to $0.59 \%$ and 0.32 to $0.33 \%$ and in grain and straw at harvest ranged from 0.22 to $0.26 \%$ and 0.06 to $0.08 \%$, respectively (Table 3 ). Different integrated nutrient management failed to show significant influence on phosphorus contents at any stage of observation.

Phosphorus uptake by shoot at 30 DAT \& 60 DAT varied from 1.52 to 6.59 and 1.63 to $12.16 \mathrm{~kg} \mathrm{ha}^{-1}$ (Table 4). At both the stages treatment STCR dose with $5 \mathrm{t}$ FYM for YT 50 $\mathrm{q} \mathrm{ha}^{-1}\left(\mathrm{~T}_{10}\right)$ recorded maximum phosphorus uptake by shoot. At 30 DAT, STCR dose with $5 \mathrm{t}$ FYM for YT $50 \mathrm{q} \mathrm{ha}^{-1}\left(\mathrm{~T}_{10}\right)$ was found statistically superior not over control but also over other treatments except 100\% GRD (100:60:40) $\left(\mathrm{T}_{4}\right)$ and 100\% GRD + 5 t FYM ha $^{-1}\left(\mathrm{~T}_{5}\right)$. At 60 DAT, STCR dose with $5 \mathrm{t}$ FYM for YT $50 \mathrm{q} \mathrm{ha}^{-1}\left(\mathrm{~T}_{10}\right)$ was found statistically superior not over control but also over other treatments however, it was found statistically similar with $100 \%$ GRD $+5 \mathrm{t}$ FYM ha ${ }^{-1}\left(\mathrm{~T}_{5}\right), 100 \%$ GRD (100:60:40) $\left(\mathrm{T}_{4}\right)$ and $100 \% \mathrm{GRD}+10 \mathrm{~kg} \mathrm{BGA} \mathrm{ha}{ }^{-1}\left(\mathrm{~T}_{7}\right)$.

The uptake of $\mathrm{P}$, as influenced by different treatments, by grain, straw and total biomass ranged from 1.68 to 12.05 and 0.64 to 4.0 , 2.33 to $15.66 \mathrm{~kg} \mathrm{ha}^{-1}$, respectively and the data are presented in Table 4. As for as phosphate uptake in grain and total biomass significantly higher value was noted in treatment STCR dose with $5 \mathrm{t}$ FYM for YT 50 $\mathrm{q} \mathrm{ha}^{-1}\left(\mathrm{~T}_{10}\right)$ as compare to rest of the treatment, however it was statistically similar to treatment $100 \%$ GRD $+5 \mathrm{t} \mathrm{FYM} \mathrm{ha}^{-1}\left(\mathrm{~T}_{5}\right)$ and $100 \% \mathrm{GRD}+10 \mathrm{~kg} \mathrm{BGA} \mathrm{ha}^{-1}\left(\mathrm{~T}_{7}\right)$.

Whereas, in case of straw, significantly higher $\mathrm{P}$ uptake over control was noted in treatment $100 \%$ GRD + 5 t FYM ha ${ }^{-1}\left(\mathrm{~T}_{5}\right)$ then other, but it was found at par to treatment STCR dose with $5 \mathrm{t}$ FYM for YT $50 \mathrm{q} \mathrm{ha}^{-1}\left(\mathrm{~T}_{10}\right)$. Application of either BGA or FYM alone could not cause significant increase in uptake of $\mathrm{P}$ by grain and straw, total biomass over control $\left(\mathrm{T}_{1}\right)$, while treatment FYM $5 \mathrm{t} \mathrm{ha}^{-1}+$ BGA@10 kg ha ${ }^{-1}\left(\mathrm{~T}_{9}\right)$ significantly increased uptake of $\mathrm{P}$ by grain, straw and total biomass over control $\left(\mathrm{T}_{1}\right)$.

A critical observation of the data reveals that the performance of treatments STCR dose with $5 \mathrm{t}$ FYM for YT $50 \mathrm{q} \mathrm{ha}^{-1}\left(\mathrm{~T}_{10}\right)$ and $100 \%$ GRD + 5 t FYM ha ${ }^{-1}\left(\mathrm{~T}_{5}\right)$, in general, was better over other treatments in increasing the uptake of $P$ in rice. Singh (2006) reported that application of 100\% NPK + FYM @10 t $\mathrm{ha}^{-1}$ was equally beneficial for nutrient uptake in comparison to other treatments.

Satyanarayana et al., (2002) also reported that application of $100 \%$ NPK +10 t FYM significantly increased the NPK uptake in comparison to application of NPK alone. The increase in NPK uptake under application of organic manures could be attributed to improvement in the nutrient availability through improving soil physicochemical and 
biological properties of the soil (Bahadur et $a l ., 2012$ ). The highest $\mathrm{N}, \mathrm{P}$ and $\mathrm{K}$ uptake was associated with treatment of soil test based $\mathrm{N}$, $\mathrm{P}$ and $\mathrm{K}$ application, FYM and green manuring. This might be due to added fertilizers, FYM and green manure, as a result better availability of $\mathrm{N}, \mathrm{P}$, and $\mathrm{K}$ in soil to the rice crop (Singh et al., 2006).

\section{Potassium content (\%) and uptake $\left(\mathrm{kg} \mathrm{ha}^{-1}\right)$}

The contents of Kin plants at 30 and 60 DAT ranged from 2.32 to $2.36 \%$ and 1.82 to 1.86 $\%$ and in grain and straw at harvest ranged from 0.48 to $0.52 \%$ and 1.08 to $1.19 \%$, respectively (Table 5). Different integrated nutrient management failed to show significant influence on potassium contents at any stage of observation.

Potassium uptake by shoot at 30 DAT \& 60 DAT varied from 6.47 to 26.32 and 9.22 to $67.65 \mathrm{~kg} \mathrm{ha}^{-1}$ (Table 6). At both the stages treatment STCR dose with $5 \mathrm{t}$ FYM for YT 50 $\mathrm{q}$ ha $^{-1}\left(\mathrm{~T}_{10}\right)$ recorded maximum potassium uptake by shoot. At 30 DAT, STCR dose with $5 \mathrm{t}$ FYM for YT $50 \mathrm{q} \mathrm{ha}^{-1}\left(\mathrm{~T}_{10}\right)$ was found statistically superior not over control but also over other treatments except $100 \%$ GRD $+5 \mathrm{t}$ FYM ha ${ }^{-1}\left(\mathrm{~T}_{5}\right)$. At 60 DAT, STCR dose with $5 \mathrm{t}$ FYM for YT $50 \mathrm{q} \mathrm{ha}^{-1}\left(\mathrm{~T}_{10}\right)$ was found statistically superior not over control but also over other treatments however, it was found statistically similar with $100 \%$ GRD $+5 \mathrm{t}$ FYM ha ${ }^{-1}\left(\mathrm{~T}_{5}\right), 100 \%$ GRD (100:60:40) $\left(\mathrm{T}_{4}\right)$ and $100 \% \mathrm{GRD}+10 \mathrm{~kg} \mathrm{BGA} \mathrm{ha}^{-1}\left(\mathrm{~T}_{7}\right)$.

The uptake of $\mathrm{K}$ influenced by different treatments, by grain, straw and total biomass ranged from 3.85 to $23.12,11.01$ to 62.93 and 14.85 to $85.94 \mathrm{~kg} \mathrm{ha}^{-1}$, respectively and data are presented in Table 6. Potassium uptake in grain was significantly higher in treatment STCR dose with $5 \mathrm{t}$ FYM for YT $50 \mathrm{q} \mathrm{ha}^{-1}$ $\left(\mathrm{T}_{10}\right)$ but it was at par to treatment $100 \%$
GRD(100:60:40) $\left(\mathrm{T}_{4}\right), 100 \%$ GRD + 5 t FYM $\mathrm{ha}^{-1}\left(\mathrm{~T}_{5}\right), 75 \%$ GRD + 5 t FYM ha-1 $\left(\mathrm{T}_{6}\right)$, $100 \%$ GRD + $10 \mathrm{~kg} \mathrm{BGA} \mathrm{ha}{ }^{-1}\left(\mathrm{~T}_{7}\right), 75 \%$ $\mathrm{GRD}+10 \mathrm{~kg} \mathrm{BGA} \mathrm{ha}^{-1}\left(\mathrm{~T}_{8}\right)$. In case of straw, significantly higher $\mathrm{K}$ uptake was observed in treatment $100 \%$ GRD + 5 t FYM ha ${ }^{-1}\left(\mathrm{~T}_{5}\right)$, however it was statistically similar to treatment $100 \%$ GRD(100:60:40) $\left(\mathrm{T}_{4}\right), 75 \%$ GRD + 5 t FYM ha ${ }^{-1}\left(\mathrm{~T}_{6}\right), 100 \%$ GRD + 10 $\mathrm{kg} \mathrm{BGA} \mathrm{ha}{ }^{-1}\left(\mathrm{~T}_{7}\right)$ and STCR dose with $5 \mathrm{t}$ FYM for YT $50 \mathrm{q} \mathrm{ha}^{-1}\left(\mathrm{~T}_{10}\right)$.

As regards to $\mathrm{K}$ uptake by total biomass, treatment $100 \%$ GRD + 5 t FYM ha ${ }^{-1}\left(\mathrm{~T}_{5}\right)$ registered significantly higher value as compared to rest of the treatment, it was comparable to $\operatorname{GRD}(100: 60: 40)\left(\mathrm{T}_{4}\right), 75 \%$ GRD + 5 t FYM ha ${ }^{-1}\left(\mathrm{~T}_{6}\right), 100 \%$ GRD + 10 $\mathrm{kg} \mathrm{BGA} \mathrm{ha}{ }^{-1}\left(\mathrm{~T}_{7}\right), 75 \%$ GRD + $10 \mathrm{~kg} \mathrm{BGA}$ $\mathrm{ha}^{-1}\left(\mathrm{~T}_{8}\right)$ and STCR dose with $5 \mathrm{t}$ FYM for YT $50 \mathrm{q} \mathrm{ha}^{-1}\left(\mathrm{~T}_{10}\right)$. Application of either BGA or FYM alone could not cause significant increase in uptake of $\mathrm{P}$ by grain and straw, total biomass over control $\left(\mathrm{T}_{1}\right)$, while treatment FYM 5 t ha ${ }^{-1}+$ BGA @ $10 \mathrm{~kg} \mathrm{ha}^{-1}$ $\left(\mathrm{T}_{9}\right)$ significantly increased uptake of $\mathrm{K}$ by grain and total biomass over control $\left(\mathrm{T}_{1}\right)$ except FYM 5 t ha ${ }^{-1}$ + BGA @ $10 \mathrm{~kg} \mathrm{ha}^{-1}\left(\mathrm{~T}_{9}\right)$ in case of straw of rice which was statistically similar with control.

Surenda et al., (2006) reported that application of farm yard manure and green manure increased the $\mathrm{K}$ content in both rice grain and straw. Application of different organic nutrients showed a significant variation in $\mathrm{K}$ uptake by rice grain and straw.

The minimum $\mathrm{K}$ uptake in rice grain and straw were obtained from control where no fertilizers were applied. Use of chemical fertilizers all the nutrients were present in balanced proportion; it might be responsible for increasing the $\mathrm{K}$ uptake by rice grain and straw (Shormy et al., 2013). 
Table.1 Effect of INM on nitrogen content (\%) in rice

\begin{tabular}{|c|c|c|c|c|}
\hline \multirow[t]{3}{*}{ Integrated nutrient management } & \multicolumn{4}{|c|}{ Nitrogen content (\%) } \\
\hline & \multirow{2}{*}{$\begin{array}{c}30 \\
\text { DAT }\end{array}$} & \multirow{2}{*}{$\begin{array}{c}60 \\
\text { DAT }\end{array}$} & \multicolumn{2}{|c|}{ At harvest } \\
\hline & & & Grain & Straw \\
\hline $\mathbf{T}_{1}$ - Control & 2.26 & 1.58 & 1.01 & 0.31 \\
\hline T$_{2}-$ FYM 5 t ha $^{-1}$ & 2.26 & 1.58 & 1.04 & 0.31 \\
\hline T $_{3^{-}}$BGA $10 \mathrm{~kg} \mathrm{ha}^{-1}$ & 2.27 & 1.59 & 1.07 & 0.31 \\
\hline$T_{4}-100 \%$ GRD (100:60:40) & 2.30 & 1.62 & 1.09 & 0.34 \\
\hline $\mathrm{T}_{5}-100 \%$ GRD + 5 t FYM ha ${ }^{-1}$ & 2.32 & 1.63 & 1.11 & 0.35 \\
\hline T6 $_{6}-75 \%$ GRD + 5 t FYM ha ${ }^{-1}$ & 2.31 & 1.63 & 1.09 & 0.34 \\
\hline$T_{7-} 100 \%$ GRD + $10 \mathrm{~kg} \mathrm{BGA} \mathrm{ha}{ }^{-1}$ & 2.32 & 1.63 & 1.11 & 0.35 \\
\hline$T_{8}-75 \%$ GRD + $10 \mathrm{~kg} \mathrm{BGA} \mathrm{ha-1}$ & 2.31 & 1.62 & 1.10 & 0.35 \\
\hline 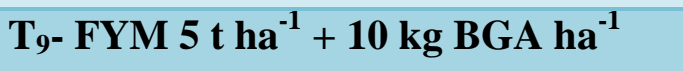 & 2.28 & 1.60 & 1.08 & 0.33 \\
\hline $\begin{array}{l}\text { T10- }_{1 T C R} \text { dose with } 5 \mathrm{t} \text { FYM for YT } \\
50 \mathrm{q} \mathrm{ha}^{-1}\end{array}$ & 2.32 & 1.63 & 1.13 & 0.33 \\
\hline SEm \pm & 0.07 & 0.07 & 0.05 & 0.01 \\
\hline $\mathrm{CD}(\mathrm{P}=0.05)$ & NS & NS & NS & NS \\
\hline
\end{tabular}

Table.2 Effect of INM on nitrogen uptake $\left(\mathrm{kg} \mathrm{ha}^{-1}\right)$ by rice

\begin{tabular}{|c|c|c|c|c|c|}
\hline \multirow[t]{3}{*}{ Integrated nutrient management } & \multicolumn{5}{|c|}{ Nitrogen uptake $\left(\mathrm{kg} \mathrm{ha}^{-1}\right)$} \\
\hline & \multirow{2}{*}{$\begin{array}{c}30 \\
\mathrm{DAT}\end{array}$} & \multirow{2}{*}{$\begin{array}{c}60 \\
\text { DAT }\end{array}$} & \multicolumn{3}{|c|}{ At harvest } \\
\hline & & & Grain & Straw & Total \\
\hline $\mathbf{T}_{1}$ - Control & 6.32 & 8.03 & 7.71 & 3.06 & 10.77 \\
\hline$T_{2}$ FYM 5 t ha $^{-1}$ & 9.20 & 15.25 & 13.85 & 5.16 & 19.00 \\
\hline T $_{3^{-}}$BGA $10 \mathrm{~kg} \mathrm{ha}^{-1}$ & 9.02 & 12.54 & 10.83 & 4.07 & 14.90 \\
\hline$T_{4-100 \%}$ GRD (100:60:40) & 22.91 & 53.56 & 46.52 & 17.24 & 63.75 \\
\hline $\mathrm{T}_{5^{-}} \mathbf{1 0 0 \%}$ GRD + 5 t FYM ha ${ }^{-1}$ & 24.76 & 56.61 & 49.45 & 18.37 & 67.82 \\
\hline $\mathrm{T}_{6}-75 \%$ GRD + 5 t FYM ha ${ }^{-1}$ & 21.15 & 50.75 & 44.14 & 16.64 & 60.79 \\
\hline$T_{7}-100 \%$ GRD + 10 kg BGA ha ${ }^{-1}$ & 23.29 & 54.87 & 48.04 & 17.99 & 66.03 \\
\hline $\mathrm{T}_{8^{-}}-75 \%$ GRD + $10 \mathrm{~kg} \mathrm{BGA} \mathrm{ha}{ }^{-1}$ & 20.80 & 49.52 & 42.56 & 16.27 & 58.84 \\
\hline${\text { T9- FYM } 5 \text { t ha }^{-1}+10 \text { kg BGA ha }}^{-1}$ & 14.09 & 20.04 & 16.96 & 6.19 & 23.15 \\
\hline $\begin{array}{l}\text { T10- }_{10 R} \text { STose with } 5 \text { t FYM for YT } \\
50 \mathrm{q} \mathrm{ha}^{-1}\end{array}$ & 25.82 & 59.25 & 51.70 & 18.16 & 69.86 \\
\hline SEm \pm & 0.66 & 2.54 & 1.58 & 0.60 & 2.03 \\
\hline $\mathrm{CD}(\mathrm{P}=0.05)$ & 1.96 & 7.55 & 4.69 & 1.79 & 6.02 \\
\hline
\end{tabular}


Table.3 Effect of INM on phosphorus content (\%) in rice

\begin{tabular}{|c|c|c|c|c|}
\hline \multirow[t]{3}{*}{ Integrated nutrient management } & \multicolumn{4}{|c|}{ Phosphorus content (\%) } \\
\hline & \multirow{2}{*}{$\begin{array}{c}30 \\
\text { DAT }\end{array}$} & \multirow{2}{*}{$\begin{array}{c}60 \\
\text { DAT }\end{array}$} & \multicolumn{2}{|c|}{ At harvest } \\
\hline & & & Grain & Straw \\
\hline $\mathbf{T}_{1-}$ - Control & 0.55 & 0.32 & 0.22 & 0.07 \\
\hline T2- FYM 5 t ha $^{-1}$ & 0.56 & 0.32 & 0.23 & 0.06 \\
\hline 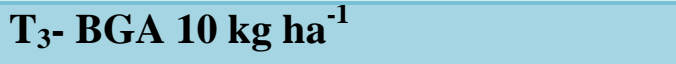 & 0.55 & 0.31 & 0.23 & 0.06 \\
\hline$T_{4}-100 \%$ GRD (100:60:40) & 0.57 & 0.31 & 0.24 & 0.07 \\
\hline $\mathrm{T}_{5^{-}} \mathbf{1 0 0 \%}$ GRD + 5 t FYM ha ${ }^{-1}$ & 0.58 & 0.33 & 0.26 & 0.08 \\
\hline$T_{6}-75 \%$ GRD + 5 t FYM ha & 0.58 & 0.32 & 0.23 & 0.07 \\
\hline $\mathrm{T}_{7}-100 \%$ GRD + $10 \mathrm{~kg} \mathrm{BGA} \mathrm{ha}{ }^{-1}$ & 0.57 & 0.32 & 0.25 & 0.07 \\
\hline $\mathrm{T}_{8}-75 \%$ GRD + $10 \mathrm{~kg} \mathrm{BGA} \mathrm{ha}{ }^{-1}$ & 0.56 & 0.31 & 0.25 & 0.07 \\
\hline 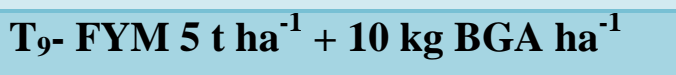 & 0.57 & 0.31 & 0.25 & 0.06 \\
\hline $\begin{array}{l}\text { T}_{10^{-}} \text {STCR dose with } 5 \text { t FYM for YT } \\
50 \mathrm{q} \mathrm{ha}^{-1}\end{array}$ & 0.59 & 0.33 & 0.26 & 0.07 \\
\hline SEm \pm & 0.03 & 0.03 & 0.02 & 0.01 \\
\hline $\mathrm{CD}(\mathrm{P}=\mathbf{0 . 0 5})$ & NS & $\mathrm{NS}$ & NS & NS \\
\hline
\end{tabular}

Table.4 Effect of INM on phosphorus uptake $\left(\mathrm{kg} \mathrm{ha}^{-1}\right)$ by rice

\begin{tabular}{|c|c|c|c|c|c|}
\hline \multirow[t]{3}{*}{ Integrated nutrient management } & \multicolumn{5}{|c|}{ Phosphorus uptake $\left(\mathrm{kg} \mathrm{ha}^{-1}\right)$} \\
\hline & \multirow{2}{*}{$30 \mathrm{DAT}$} & \multirow[t]{2}{*}{$60 \mathrm{DAT}$} & \multicolumn{3}{|c|}{ At harvest } \\
\hline & & & Grain & Straw & Total \\
\hline $\mathbf{T}_{1-}$ - Control & 1.52 & 1.63 & 1.68 & 0.64 & 2.33 \\
\hline T2- FYM 5 t ha $^{-1}$ & 2.28 & 3.11 & 3.14 & 1.05 & 4.19 \\
\hline T $_{3^{-}}$BGA $10 \mathrm{~kg} \mathrm{ha}^{-1}$ & 2.19 & 2.47 & 2.33 & 0.81 & 3.13 \\
\hline$T_{4}-100 \%$ GRD (100:60:40) & 5.76 & 10.42 & 10.03 & 3.44 & 13.47 \\
\hline T $^{-}-100 \%$ GRD + 5 t FYM ha ${ }^{-1}$ & 6.19 & 11.38 & 11.62 & 4.00 & 15.62 \\
\hline T6 $_{6}-75 \%$ GRD + 5 t FYM ha & 5.33 & 9.95 & 9.18 & 3.36 & 12.54 \\
\hline$T_{7}-100 \%$ GRD + $10 \mathrm{~kg} \mathrm{BGA} \mathrm{ha-1}$ & 5.73 & 10.77 & 10.76 & 3.43 & 14.18 \\
\hline$T_{8}-75 \%$ GRD + 10 kg BGA ha ${ }^{-1}$ & 5.07 & 9.61 & 9.81 & 3.05 & 12.86 \\
\hline 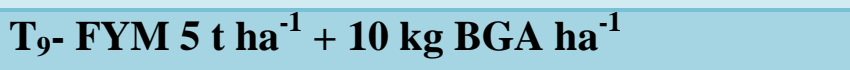 & 3.51 & 3.93 & 3.95 & 1.19 & 5.13 \\
\hline $\mathrm{T}_{10^{-}}$STCR dose with $5 \mathrm{t}$ FYM for YT $50 \mathrm{q} \mathrm{ha}^{-1}$ & 6.59 & 12.16 & 12.05 & 3.61 & 15.66 \\
\hline SEm \pm & 0.28 & 0.69 & 0.61 & 0.16 & 0.72 \\
\hline $\mathrm{CD}(\mathrm{P}=\mathbf{0 . 0 5})$ & 0.83 & 2.05 & 1.80 & 0.48 & 2.14 \\
\hline
\end{tabular}


Table.5 Effect of INM on potassium content (\%) in rice

\begin{tabular}{|c|c|c|c|c|}
\hline \multirow[t]{3}{*}{ Integrated nutrient management } & \multicolumn{4}{|c|}{ Potassium content (\%) } \\
\hline & \multirow[t]{2}{*}{$30 \mathrm{DAT}$} & \multirow[t]{2}{*}{60 DAT } & \multicolumn{2}{|c|}{ At harvest } \\
\hline & & & Grain & Straw \\
\hline $\mathbf{T}_{1-}$ Control & 2.32 & 1.82 & 0.48 & 1.08 \\
\hline T2- FYM 5 t ha $^{-1}$ & 2.30 & 1.83 & 0.51 & 1.14 \\
\hline T $_{3-\text { BGA }} 10 \mathrm{~kg} \mathrm{ha}^{-1}$ & 2.31 & 1.82 & 0.51 & 1.18 \\
\hline$T_{4^{-}}$100\% GRD (100:60:40) & 2.34 & 1.84 & 0.52 & 1.19 \\
\hline $\mathrm{T}_{5}-100 \%$ GRD + 5 t FYM ha ${ }^{-1}$ & 2.36 & 1.86 & 0.52 & 1.19 \\
\hline $\mathrm{T}_{6}-75 \%$ GRD + 5 t FYM ha ${ }^{-1}$ & 2.36 & 1.85 & 0.50 & 1.13 \\
\hline$T_{7}-100 \%$ GRD + $10 \mathrm{~kg} \mathrm{BGA} \mathrm{ha}{ }^{-1}$ & 2.36 & 1.84 & 0.51 & 1.19 \\
\hline$T_{8}-75 \%$ GRD + $10 \mathrm{~kg} \mathrm{BGA} \mathrm{ha}^{-1}$ & 2.35 & 1.84 & 0.52 & 1.13 \\
\hline${\text { T9- FYM } 5 \text { t ha }^{-1}+10 \text { kg BGA ha }}^{-1}$ & 2.33 & 1.84 & 0.48 & 1.14 \\
\hline $\begin{array}{l}T_{10^{-}} \text {STCR dose with } 5 \text { t FYM for YT } 50 \text { q } \\
\text { ha }^{-1}\end{array}$ & 2.36 & 1.86 & 0.51 & 1.17 \\
\hline SEm \pm & 0.07 & 0.09 & 0.04 & 0.08 \\
\hline $\mathrm{CD}(\mathrm{P}=0.05)$ & NS & NS & NS & NS \\
\hline
\end{tabular}

Table.6 Effect of INM on potassium uptake $\left(\mathrm{kg} \mathrm{ha}^{-1}\right)$ by rice

\begin{tabular}{|c|c|c|c|c|c|}
\hline \multirow[t]{3}{*}{ Integrated nutrient management } & \multicolumn{5}{|c|}{ Potassium uptake $\left(\mathrm{kg} \mathrm{ha}^{-1}\right)$} \\
\hline & \multirow{2}{*}{$\begin{array}{c}30 \\
\text { DAT }\end{array}$} & \multirow{2}{*}{$\begin{array}{c}60 \\
\text { DAT }\end{array}$} & \multicolumn{3}{|c|}{ At harvest } \\
\hline & & & Grain & Straw & Total \\
\hline $\mathbf{T}_{1-}$ Control & 6.47 & 9.22 & 3.85 & 11.01 & 14.85 \\
\hline 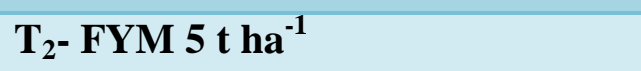 & 9.31 & 17.68 & 7.13 & 20.13 & 27.26 \\
\hline 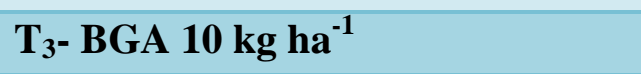 & 9.17 & 14.38 & 5.10 & 14.65 & 19.75 \\
\hline$T_{4-}-100 \%$ GRD (100:60:40) & 23.28 & 60.81 & 21.47 & 56.24 & 77.72 \\
\hline $\mathrm{T}_{5^{-}} 100 \%$ GRD + 5 t FYM ha ${ }^{-1}$ & 25.25 & 64.58 & 23.01 & 62.93 & 85.94 \\
\hline T6- $_{6}-75 \%$ GRD + 5 t FYM ha & 21.59 & 57.34 & 21.32 & 53.64 & 74.95 \\
\hline$T_{7}-100 \%$ GRD + $10 \mathrm{~kg} \mathrm{BGA} \mathrm{ha}^{-1}$ & 23.81 & 61.73 & 20.40 & 57.21 & 77.61 \\
\hline $\mathrm{T}_{8}-75 \%$ GRD + $10 \mathrm{~kg} \mathrm{BGA} \mathrm{ha}$ & 21.22 & 55.90 & 20.67 & 50.97 & 71.64 \\
\hline${\text { T9- FYM } 5 \text { t ha }^{-1}+10 \text { kg BGA ha }}^{-1}$ & 14.44 & 23.06 & 8.04 & 22.11 & 30.15 \\
\hline $\begin{array}{l}\text { T10- }_{1 T C R} \text { dose with } 5 \mathrm{t} \text { FYM for } \\
\text { YT } 50 \mathrm{q} \mathrm{ha}^{-1}\end{array}$ & 26.32 & 67.65 & 23.12 & 61.05 & 84.17 \\
\hline SEm \pm & 0.83 & 2.51 & 1.26 & 3.74 & 4.95 \\
\hline $\mathrm{CD}(\mathbf{P}=\mathbf{0 . 0 5})$ & 2.47 & 7.45 & 3.76 & 11.12 & 14.71 \\
\hline
\end{tabular}


Table.7 Effect of INM on grain and straw yield of rice $\left(\mathrm{q} \mathrm{ha}^{-1}\right)$

\begin{tabular}{|c|c|c|}
\hline Integrated nutrient management & $\begin{array}{c}\text { Grain yield } \\
\quad\left(q \text { ha }^{-1}\right)\end{array}$ & $\begin{array}{c}\text { Straw yield } \\
\quad\left(\mathbf{q} \mathbf{h a}^{-1}\right)\end{array}$ \\
\hline $\mathbf{T}_{1}$ - Control & 7.79 & 9.97 \\
\hline 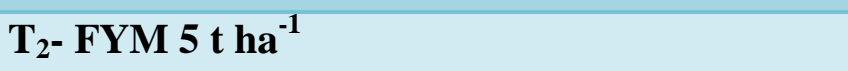 & 13.43 & 16.85 \\
\hline$T_{3^{-}}$BGA $10 \mathrm{~kg} \mathrm{ha}^{-1}$ & 10.13 & 13.05 \\
\hline$T_{4}-100 \%$ GRD (100:60:40) & 42.60 & 50.68 \\
\hline$T_{5}-100 \%$ GRD + 5 t FYM ha ${ }^{-1}$ & 44.76 & 53.38 \\
\hline$T_{6}=75 \%$ GRD + 5 t FYM ha ${ }^{-1}$ & 40.46 & 48.32 \\
\hline$T_{7-100 \%}$ GRD + 10 kg BGA ha ${ }^{-1}$ & 43.06 & 51.25 \\
\hline$T_{8^{-}} 75 \%$ GRD + $10 \mathrm{~kg} \mathrm{BGA} \mathrm{ha}^{-1}$ & 38.77 & 46.62 \\
\hline 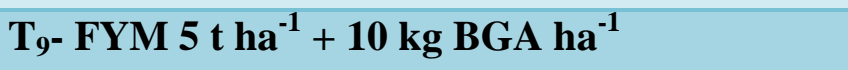 & 15.84 & 19.08 \\
\hline$T_{10^{-}}$STCR dose with 5 t FYM for YT $50 \mathrm{q} \mathrm{ha}^{-1}$ & 45.93 & 54.95 \\
\hline SEm \pm & 1.33 & 1.74 \\
\hline $\mathrm{CD}(\mathrm{P}=0.05)$ & 3.96 & 5.16 \\
\hline
\end{tabular}

GRD: General recommended dose of fertilizers, FYM: Farmyard manure, BGA: Blue Green algae, STCR: Soil test crop response, YT: Yield target

\section{Grain and straw yield}

The grain and straw yield of rice as influenced by integrated nutrient management. The grain and straw yield of rice increased from 7.79 to 45.93 and 9.97 to $54.95 \mathrm{~kg} \mathrm{ha}^{-1}$, respectively (Table 7). The higher grain and straw yield of rice was in treatment STCR dose with $5 \mathrm{t}$ FYMas compare to rest of the treatments. However, it was statistically similar to $100 \%$ GRD $+5 \mathrm{t}$ FYM ha ${ }^{-1}, 100 \%$ GRD+ $10 \mathrm{~kg} \mathrm{BGA} \mathrm{ha}^{-1}$ and 100\% GRD (100:60:40).

Application of BGA alone could not cause significant increase in yield of grain and straw over control, while FYM individually and in combination with BGA treatment FYM $5 \mathrm{t} \mathrm{ha}$ ${ }^{1}+10 \mathrm{~kg} \mathrm{BGA} \mathrm{ha}{ }^{-1}$ significantly increased grain and straw yield of rice over control. The integrated use of fertilizers with organic manures viz., FYM and BGA might have added huge quantity of organic matter in soil that increased grain and straw yield. This might be due to the improvement in physicochemical properties of soil that resulted in better productivity by increasing availability of plant nutrients (Chaudhary and Thakur, 2007). Further, the addition of organic matter also maintains regular supply of macro and micronutrients in soil resulting in higher yields. These results are in conformity with the finding of Gupta et al., (2006).

The N, P and $\mathrm{K}$ content at different stages of rice was found non-significant. The uptake of Nand $P$ by grain and total biomass significantly higher value was noted in treatment STCR dose with $5 \mathrm{t} \mathrm{FYM} \mathrm{for} \mathrm{YT} 50$ $\mathrm{q} \mathrm{ha}^{-1}\left(\mathrm{~T}_{10}\right)$ as compare to rest of the treatment, however it was statistically similar to treatment $100 \%$ GRD + $5 \mathrm{t} \mathrm{FYM} \mathrm{ha}^{-1}\left(\mathrm{~T}_{5}\right)$. Whereas, in case of straw, significantly higher $\mathrm{N}$ and $\mathrm{P}$ uptake over cotrol was noted in treatment $100 \%$ GRD + 5 t FYM ha $^{-1}\left(\mathrm{~T}_{5}\right)$ then other, but it was found at par to treatment STCR dose with $5 \mathrm{t}$ FYM for YT $50 \mathrm{q} \mathrm{ha}^{-1}$ 
$\left(\mathrm{T}_{10}\right)$. As for as $\mathrm{K}$ uptake by grain was significantly higher in treatment STCR dose with $5 \mathrm{t}$ FYM for YT $50 \mathrm{q} \mathrm{ha}^{-1}\left(\mathrm{~T}_{10}\right)$ but in case of straw and total biomass, significantly higher $\mathrm{K}$ uptake was observed in treatment $100 \%$ GRD + 5 t FYM ha ${ }^{-1}\left(\mathrm{~T}_{5}\right)$. A critical observation of the data reveals that the performance of treatments STCR dose with 5 t FYM for YT $50 \mathrm{q} \mathrm{ha}^{-1}\left(\mathrm{~T}_{10}\right)$ and $100 \%$ GRD +5 t FYM ha ${ }^{-1}\left(\mathrm{~T}_{5}\right)$, in general was better over other treatments in increasing the uptake of $\mathrm{N}, \mathrm{P}$ and $\mathrm{K}$ and yield in rice crop.

\section{Acknowledgment}

The authors are thankful to College of Agriculture, IGKV, Raipur, College of Agriculture Janjgir-Champa (C.G.) and Department of soil Science and agricultural Chemistry for providing necessary laboratory facilities. We are thankful to the anonymous reviewers who have provided their valuable suggestions to improve the manuscript.

\section{References}

Babu, M. V. S., Reddy, C. M., Subramaniam, A. and Balaguravaiah. 2007. Effect of integrated use of organic and inorganic fertilizers on soil properties and yield of sugarcane. Journal of the IndianSociety of Soil Science, 55: 161-6.

Bahadur, L., Tiwari, D.D., Mishra, J. and Gupta, B.R. 2012.Effect of integrated nutrient management on yield, microbialpopulation and changes in soil properties under rice-wheatcropping system in sodic soil.Journal of the Indian Society of Soil Science, 60(4): 326-329.

Chapman, L. and Pratt, E. 1961. Soil chemical analysis Prentice hall of India Private limited. New Delhi.

Chaudhary, S.K. and Thakur, R.B. 2007. Efficient farm yard management for sustained productivity of rice (Oryza sativa) - wheat (Triticumaestivum) cropping system. Indian Journal of Agricultural Sciences, 77(7): 443-444.

Gupta, V., Sharma, R.S. and Vishvakarma, S.K. 2006. Long-term effect of integrated nutrient management on yield sustainability and soil fertility of rice (Oryza Sativa) - $\quad$ Wheat (Triticumaestivum) cropping system. Indian Journal of Agronomy, 51(3): 160-164.

Jackson, M.L. 1967. Soil chemical analysis, pentice hall of india Pvt. Ltd., New Delhi.

Prasad, J., Karmakar, S., Kumar, R. and Mishra, B. 2010. Influence of integrated nutrient management on yield and soil properties in maize-wheat cropping system in an Alfisol of Jharkhand. Journal of the Indian Society of Soil Science, 58: 200-204.

Rama Lakshmi, ChS., Rao, P.C., Sreelatha, M., Madhavi, G., Padmaja, P.V., Rao, P.V., Sireesha, A. 2012. Nitrogen Use Efficiency and Production Efficiency of Rice Under Rice-Pulse Cropping System with Integrated Nutrient Management. J. Rice Res. 5(1\&2):4251.

Satyanarayna, V., Vara-Prasad, P.V., Murthy, V.R.K. and Boote, K.J. 2002. Influence of integrated use of farmyard manure and inorganic fertilizers on yield and yield components of irrigated lowland rice. Journalof Plant Nutrition, 25: 2081-2090.

Shormy, S.A.S., Chowdhury, M.A.H., Saha, B.K. andHaque, M.A. 2013. Effects of different sources of organic materials on nutrient contents and their uptake by $\mathrm{T}$. aman rice. J. Agrofor. Environ., 7(1): 37-40.

Singh, P., Singh, S. and Chaubey A.K. 2006.Effect of INM on soil fertility, nutrient uptake and yield in riceEuropean dill (Anethumgraveolens) 
cropping system. International J. agric. Sci., 2(2): 613-617.

Singh, V. 2006. Productivity and economics of rice (Oryza sativa) - wheat (Triticum aestivum) cropping system under integrated nutrient supply system in recently reclaimed sodic soil. Indian Journal of Agronomy, 54:81-84.

Subehia, S.K. and Sepehya, S. 2012. Influence of long-term nitrogen substitution through organics on yield, uptake and available nutrients in a ricewheat system in an acidic soil. Journal of the Indian Society of Soil Science,
60(3): 213-217.

Surendra, S., Singh, R.N., Prasad, J. and Singh, B.P. 2006.Effect of integrated nutrient management on yield and uptake of nutrients by rice and soil fertility in rainfed uplands. Journal of the Indian Society of Soil Science, 54(3): 327-330.

Verma, Arvind, Nepalia, V. and Kanthaliya, P. C. 2005. Effect of continuous cropping and fertilization on crop yields and nutrient status of a Typic Haplustept. Journal of the Indian Society of Soil Science.53: 365-368.

\section{How to cite this article:}

Yugal Kishor Sahu and Chaubey. A. K. 2020. Effect of Integrated Nutrient Management on Nutrient Content, Uptake and Yield of Rice Crop in Inceptisol. Int.J.Curr.Microbiol.App.Sci. 9(03): 2531-2541. doi: https://doi.org/10.20546/ijcmas.2020.903.290 